\title{
BREZSTROPA JAMA V PODBOJEVEM LAZU, RAKOV ŠKOCJAN
}

dr. Uroš Stepišnik

Oddelek za geografijo, Filozofska fakulteta Univerze v Ljubljani

Aškerčeva 2, SI-I000 Ljubljana

e-mail: urosstepisnik@hotmail.com

Mateja Ferk, Blaž Kodelja, Boštjan Burger, Maja Abramović, Simona Peterca

Študentje geografije, Oddelek za geografijo, Filozofska fakulteta Univerze v Ljubljani

Aškerčeva 2, SI-I000 Ljubljana

Izvirni znanstveni članek

COBISS 1.01

\section{Izvleček}

Predstavljena je brezstropa jama v Podbojevem lazu, v severozahodnem delu Rakovega Škocjana. Opisane so morfometrične in morfogenetske značilnosti več odsekov brezstrope jame in njene okolice. Brezstropa jama se je razvila iz epifreatičnega jamskega sistema, ki je deloval kot odtočni sistem iz doline Raka. Na podlagi podrobne morfometrične analize pobočij je bilo ugotovljeno, da brezstropa jama ni nastala sočasno. Zaradi neuravnanega površja je bil jamski strop denudiran postopoma.

Ključne besede: kras, Rakov Škocjan, brezstropa jama, električna upornost tal (ERI)

\section{DENUDED CAVE IN PODBOJEV LAZ, RAKOV ŠKOCJAN}

\begin{abstract}
This paper presents a denuded cave situated in the area of Podbojev laz, on the northwestern side of the Rakov Škocjan. Morphometric and morphogenetic properties of several sections of the denuded cave and its surroundings are described in detail. The denuded cave developed from an epiphreatic cave system which used to function as an outflow cave system from the Rak valley. Morphometrical analysis of the slopes show that the denuded cave was developed in stages. As the surrounding surface is not flattened, the cave roof must have been denuded gradually.
\end{abstract}

Key words: karst, Rakov Škocjan, denuded cave, electrical resistivity imaging (ERI) 


\section{UVOD}

Kotlina Rakov Škocjan se nahaja v severozahodnem delu Notranjskega podolja. Leži med Planinskim ter Unško-Rakovškim kraškim poljem na severu in Cerkniškim poljem na jugovzhodu. Na zahodu se nad kotlino dviguje nižji hrib Tolsti vrh (681 m), na jugu se visoko dvigajo Javorniki.

Območje so zaradi geomorfološke in hidrološke pestrosti opisovali že mnogi avtorji od Valvasorja naprej. Prvega pravega znanstvenega preučevanja kotline Rakovega Škocjana se je lotil Šerko (1949), a zaradi nenadne smrti svojega raziskovanja ni zaključil. Njegove terenske zapiske in opažanja je po njegovi smrti uredil in leta 1949 objavil Melik. Šerko (1949) je nakazal nekatere oblike v reliefu, ki do danes niso bile preverjene in preučene, med drugim višje uravnave v živoskalni podlagi na enotnih nivojih v okoliških pobočjih kotline (Šerko 1949). Kasnejša znanstvena preučevanja so bila usmerjena predvsem v hidrološke (Gospodarič in sod. 1982) in geološke značilnosti doline Raka (Habič in Gospodarič 1987). Poljudne regionalne opise, ki med drugim izpostavljajo geomorfološko pestrost doline Raka in okolice, sta napisala P. Kunaver (1966) in Silan (1995). Z dosedanjimi raziskavami obravnavanega območja so bili preučeni predvsem Mali in Veliki naravni most, kraški izviri $\mathrm{v}$ dolini ter jame pritočnega in odtočnega dela. V okolici doline Raka se poleg opisovanih površinskih oblik nahaja še cela vrsta zanimivih geomorfoloških pojavov, ki v preteklosti niso bili obravnavani v literaturi, a pomembno prispevajo k poznavanju pestrosti in razumevanju razvoja kotline Rakovega Škocjana.

Namen naše raziskave je geomorfološki pregled oblik in procesov v severozahodnem, ponornem delu Rakovega Škocjana, kjer se na manjšem območju v okolici Podbojevega laza nahaja več jarkov brezstropih jam. Cilj raziskave je podrobna morfografska predstavitev oblik, ki se nahajajo na tem območju, ter morfogenetska interpretacija razvoja jamskega sistema, brezstropih jam in okoliškega reliefa.

Raziskava je obsegala podroben pregled geološke, hidrološke, speleološke in geomorfološke literature o območju kraške doline Raka in okolice. Morfografska analiza območja je vključevala terenski pregled območja in podrobno geomorfološko kartiranje brezstropih jam in njihove okolice. Morfometrična analiza je obsegala podrobno merjenje oblik brezstropih jam ter merjenje prečnih profilov preko jarkov brezstropih jam. Za potrebe morfogenetske analize so bile narejene granulometrične in petrološke analize ilovnatih sedimentov, ki zapolnjujejo dno Podbojevega laza in mestoma jarke brezstropih jam. Globina teh sedimentov nad karbonatno matično podlago je bila izmerjena z merilcem električne upornosti tal Supersting R1/IP. Uporabljena je bila metoda dipol-dipol, ki se je pri preteklih meritvah v podobnih okoljih izkazala kot najprimernejša (Stepišnik in sod. 2007; Stepišnik in Mihevc 2008). Interpretacija električne upornosti tal je bila izdelana s programskim orodjem EarthImager 2D Resistivity Inversion Software, ki ga je izdelal Advanced Geosciences. Morfogenetska interpretacija območja je vključevala podrobno analizo geomorfološke karte območja in prečnih profilov preko jarkov brezstropih jam. 


\section{BREZSTROPE JAME}

Brezstropa jama je končni stadij razvoja jame, ko ji je predvsem zaradi kemične denudacije, delno tudi zaradi udiranja, strop popolnoma razpadel oziroma je bil denudiran. Običajno so brezstrope jame podolgovate, jarkom podobne plitve kotanje v kraškem površju. $\mathrm{V}$ njih najdemo sigo, ki v naših klimatskih pogojih nastaja samo v jamskem okolju, ali pa alogene sedimente, ki jih je v jamske rove akumuliral podzemni vodni tok.

Že ob koncu 19. st. se je pojavilo prvo poročilo o razpadu jamskih prostorov v bližini površja z udiranjem jamskega stropa, ki ga je napisal Dawkins (1876). V istem obdobju je Kraus (1894) menil, da so take jame stopnja v razvoju med jamami in soteskami ter vrtačami. Kot primer razpada jame sta bila opisana Rakov Škocjan in kanjon Reke pred Škocjanskimi jamami. Razpad jamskih sistemov naj bi bil posledica površinskih in podzemskih procesov, ki tanjšajo strop, njihov rezultat pa je udor jamskega stropa in preoblikovanje v površinsko obliko. Kot primer recentnega preoblikovanja jamskih rovov je Kraus (1984) navedel jamo Veliki Lončarevec pri Velikem Otoku (katastrska številka 1606; Kataster jam JZS 2008), kjer sta se v stropu, tanjšem od enega metra, oblikovali že dve okni (Mais 1999). Opisan proces preoblikovanja jamskih rovov z udorom ni pojasnjeval oblikovanja podolgovatih globeli in akumulacije fluvialnih sedimentov na kraškem površju. Kasnejši avtorji (Melik 1955; D’Ambrosi 1966; Radinja 1967) so te oblike in sedimente pripisovali površinskim rekam, ki naj bi tekle po kraškem površju. Ker so dokazovali površinski tok rek, so podolgovate kotanje $\mathrm{v}$ kraškem površju in alogene sedimente $\mathrm{v}$ njih opisovali kot suhe doline in $\mathrm{s}$ tem $\mathrm{v}$ okviru cikličnega modela razvoja površja dokazovali obstoj t.i. 'predkraške faze' (Mihevc 2007). Klimatski geomorfologi so alogene sedimente na krasu pripisovali specifičnemu selektivnemu preperevanju v različnih klimah (Radinja 1972).

Interpretacija podolgovatih globeli in alogenih sedimentov na krasu se je spremenila pri raziskavah ob gradnji avtoceste čez Kras (Mihevc 1996) in ob sistematičnem geomorfološkem in speleološkem preučevanju Divaškega krasa (Mihevc 2001). Odkritih je bilo veliko število nekdanjih jam, ki jim je denudacija že popolnoma odstranila celoten strop. Zapolnjene so bile $\mathrm{z}$ različnimi alogenimi sedimenti in sigo, katera nedvomno dokazuje genezo teh oblik $\mathrm{v}$ podzemlju.

Oblika brezstropih jam je odvisna od oblikovanosti jamskega sistema, iz katerega se razvijejo, in oblikovanosti površja nad njim. Če gre za vertikalne ali poševne jamske rove, se ob denudaciji stropa kažejo kot bolj ali manj okrogle kotanje na kraškem površju, ki so po morfometričnih značilnostih najbližje vrtačam. V primeru vodoravnih, največkrat epifreatičnih jamskih rovov, ki so denudirani v uravnanem kraškem površju, nastanejo daljši odseki jarkov na površju. Te oblike so bile poimenovane brezstrope jame (Mihevc 1996; 2001).

Definiranje in interpretacija procesov nastanka in preoblikovanja brezstropih jam je odprlo nov pogled na razumevanje razvoja krasa. Pojasnjen je bil izvor marsikatere površinske kraške oblike, akumulacije alogenih sedimentov na površju in dinamika denudacije kraškega površja (Mihevc 2007). 


\section{KOTLINA RAKOV ŠKOCJAN}

V nizu kraških polj Notranjskega podolja, med Cerkniškim in Planinskim poljem, leži 3,5 $\mathrm{km}$ dolga in $1,5 \mathrm{~km}$ široka kotlina Rakov Škocjan. V literaturi (Šerko 1949) se raziskovano območje navaja pod različnimi imeni. Za osrednje območje od izvirov Raka do ponorov se uporablja ime dolina Raka ali Rakov Škocjan. Širše območje, za katerega v članku uporabljamo ime kotlina Rakov Škocjan, obsega tudi severozahodno kotanjo Podbojev laz. To širše območje starejša literatura navaja kot Rakovško uvalo (Šerko 1949). Dno kotline ni homogeno, ampak sta $v$ njej oblikovani dve kotanji. $V$ jugovzhodnem delu je kraška dolina Raka, ki je okoli $1,5 \mathrm{~km}$ dolga in do $0,5 \mathrm{~km}$ široka. Dno doline je na nadmorski višini okoli 500 m. Po njej teče ponikalnica Rak, ki izvira iz Zelških jam (kat. št. 576; Kataster jam JZS 2008) in ponika v Tkalca jamo (kat. št. 857; Kataster jam JZS 2008). Severozahodno od doline se nahaja kotanja s toponimom Podbojev laz. Dolga je okoli $500 \mathrm{~m}$ in široka do 250 $\mathrm{m}$. Dno kotanje je relativno uravnano na nadmorski višini $520 \mathrm{~m}$. V njej se ne pojavlja tekoča ali stoječa voda. Kotanji loči pregib na nadmorski višini $530 \mathrm{~m}$. Podbojev laz predstavlja nekakšno neaktivno nadaljevanje doline Raka, kjer je bilo med drugim identificiranih več jarkov brezstropih jam (slika 1).

Slika 1: Lega Podbojevega laza v kotlini Rakov Škocjan

Figure 1: Location of the Podbojev laz within the basin of Rakov Škocjan

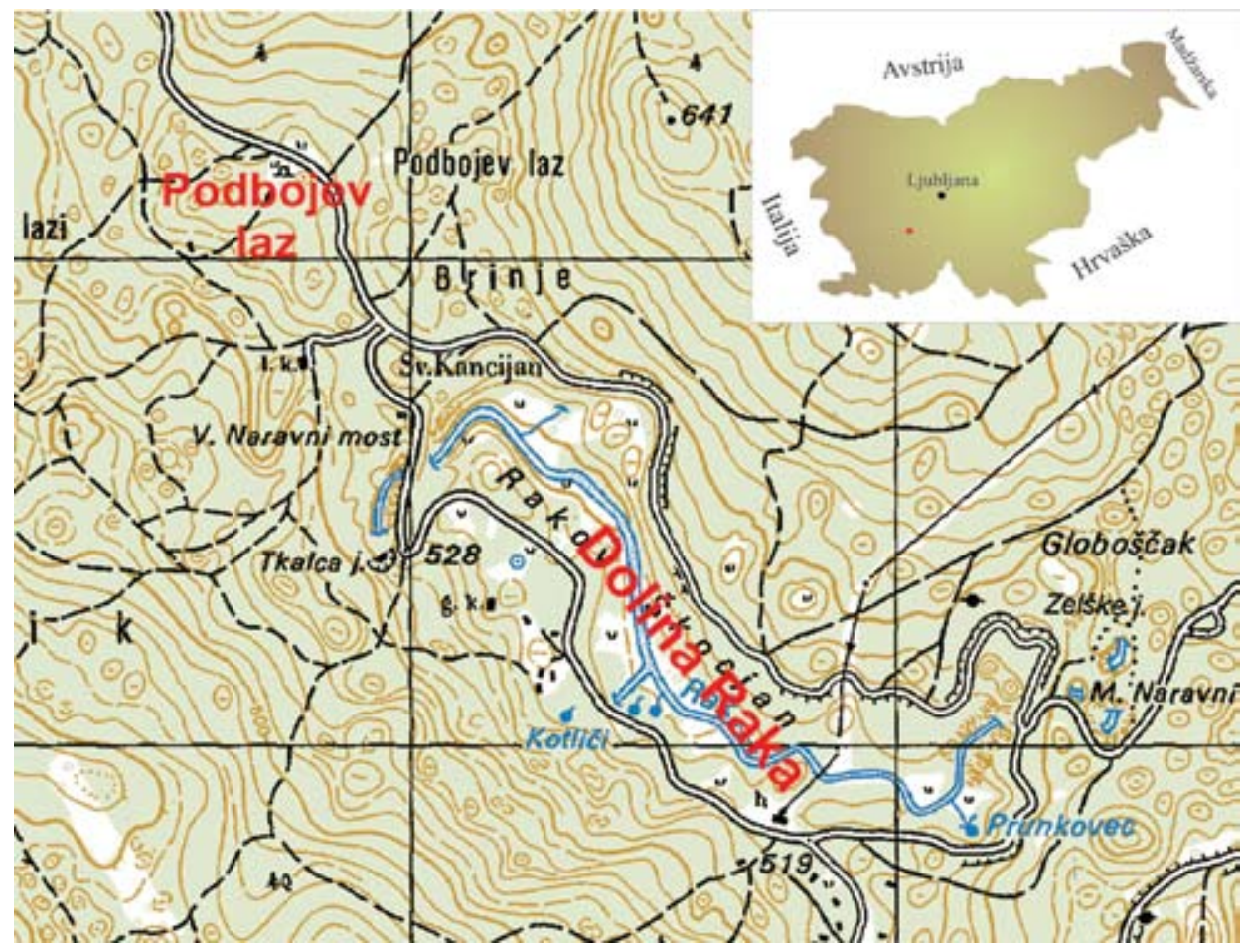


Reka Rak izvira v zatrepni dolini iz Zelških jam. Sprva teče po ozki kanjonski dolini s strmimi stenami. Ta del doline je $200 \mathrm{~m}$ dolg, povprečno $75 \mathrm{~m}$ širok in 15-20 m globok. Sledi širši del doline, ki je okoli 1300 m dolg in do 200 m širok. Dno je 10-15 m poglobljeno v širšo uravnavo v živoskalni podlagi. Široka naplavna ravnica Raka, ki je oblikovana na nadmorski višini 500-510 m, daje dolini funkcijski značaj kraškega polja. Ta del se zaključi s $40 \mathrm{~m}$ visoko steno, skozi katero odteka Rak pod Velikim naravnim mostom v $150 \mathrm{~m}$ dolgo, $50 \mathrm{~m}$ široko in $40 \mathrm{~m}$ globoko Škocjansko udornico pred ponorno Tkalca jamo.

Kotlina Rakov Škocjan leži v spodnjekrednih apnencih z vložki dolomita in breče. Skladi vpadajo za največ $30^{\circ}$ proti zahodu, jugozahodu in severozahodu (Čar in Gospodarič 1983). Prepreženi so z vzdolžnimi in prečnimi prelomi ter z razpokami, ki potekajo od severa proti jugu ne glede na usmerjenost plasti. Te razpoke sestavljajo razpoklinske cone. Najpogostejši prelomi na območju kotline Rakovega Škocjana potekajo v dinarski smeri (Gospodarič in sod. 1982).

Rak je hidrološko del cerkniškega kraka sistema kraške Ljubljanice. Voda, ki ponika ob severozahodnem robu Cerkniškega polja v ponorne jame na nadmorski višini $550 \mathrm{~m}$, izvira iz Zelških jam na nadmorski višini $505 \mathrm{~m}$ pod imenom Rak. V dolini so predvsem na zahodni in južni strani močni izviri voda izpod Javornikov. Najbolj izdaten in najbolj stalen izvir so Očesa ali Kotliči, ki prispevajo od četrtine do treh četrtin vode Raka. Edini izviri na desnem bregu Raka so izviri pod Farovko, ki so občasni in neizdatni (Gospodarič in sod. 1982). Količina vode in pretok v strugi Raka sta povezana tudi z vodnimi razmerami na Cerkniškem polju. Ob visokih vodostajih na Cerkniškem polju naraste pretok Raka na $25 \mathrm{~m}^{3} / \mathrm{s}$. Prav tako naraste pretok v izviru Kotliči na $25 \mathrm{~m}^{3} / \mathrm{s}$. Ker je ponor v Tkalca jami, na nadmorski višini $500 \mathrm{~m}$, zmožen požirati največ $30 \mathrm{~m}^{3} / \mathrm{s}$ vode, začne v dolini Raka voda zastajati in nastane do $10 \mathrm{~m}$ globoko jezero. Nivo poplavne vode se torej lahko dvigne do nadmorske višine $510 \mathrm{~m}$ (Habič in Gospodarič 1987).

\section{BREZSTROPA JAMA V PODBOJEVEM LAZU}

Brezstropa jama v Podbojevem lazu leži v severozahodnem nadaljevanju doline Raka, okoli pol kilometra severozahodno od ponora Raka v Tkalca jamo. Osrednji del brezstrope jame predstavlja manjša kotanja s toponimom Podbojev laz, po kateri se imenuje celoten severozahodni del kotline Rakov Škocjan. Zapolnjuje jo ilovnata uravnava na nadmorski višini $520 \mathrm{~m}$. Od Podbojevega laza potekajo fragmenti brezstrope jame v smeri juga in zahoda. Skupna dolžina jarkov brezstrope jame, ki so mestoma večkrat prekinjeni, je okoli $620 \mathrm{~m}$.

Območje brezstrope jame gradijo spodnjekredni skladi debeline do $0,5 \mathrm{~m}$. Vpad skladov je $14^{\circ} \mathrm{v}$ smeri $240-245^{\circ}$. Preko območja poteka več prelomov v smeri sever-jug. V enaki smeri je oblikovana tudi večina fragmentov brezstrope jame.

Dva jarka se iztečeta neposredno v Podbojev laz, nekateri pa potonejo v okoliško kraško površje. Ob zaključku teh rovov se nahajajo jame ali manjše udornice, ki nakazujejo na izvor jarkov in predvideno smer podzemnega nadaljevanja jam. Jame so bile zapolnjene z drobnozrnatim sedimentom, ki se pojavlja v dneh jarkov kot ilovnat material. Preučevana brezstropa jama je prostorsko razdeljena $\mathrm{v}$ dva dela, južno in zahodno od Podbojevega laza. 
Zaradi razlik v morfologiji jo v nadaljevanju delimo v tri odseke: južni odsek, zahodni odsek in osrednjo kotanjo s toponimom Podbojev laz (slika 2).

Slika 2: Obseg odsekov brezstrope jame v Podbojevem lazu

Figure 2: Extent of sections of the denuded cave in the Podbojev laz

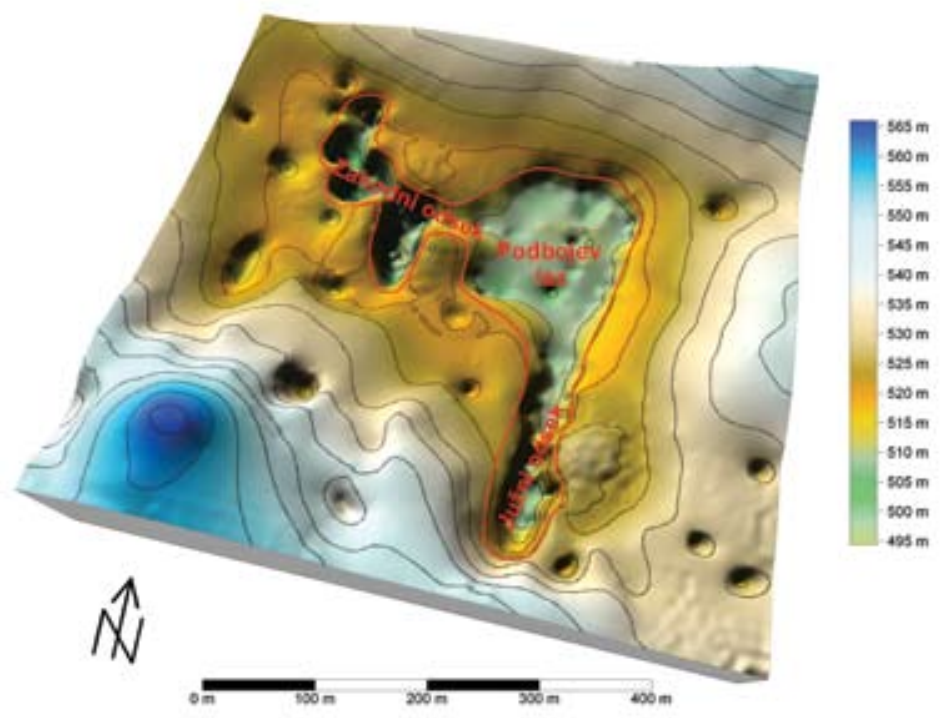

\section{I. Južni odsek}

Južni odsek brezstrope jame predstavlja 250 m dolg jarek v smeri sever-jug. Površje v okolici se spušča proti severu, zato je ta odsek v najglobljem južnem delu okoli $20 \mathrm{~m}$ globok, v severnem delu pa je obod le $3 \mathrm{~m}$ nad dnom jarka. Šrina jarka v najširšem južnem delu meri $45 \mathrm{~m}$, v najožjem osrednjem delu pa okoli $15 \mathrm{~m}$. Dno jarka zapolnjuje ilovnat sediment, ki je na dveh mestih v južnem in osrednjem delu delno izpran. Granulometrične analize vzorcev ilovnatega sedimenta so pokazale, da sediment vsebuje 58-70 \% melja, 19-27\% gline in 8-19 \% peska, kar ga uvršča v teksturni razred meljaste ilovice. Petrografske analize ilovnatega sedimenta so pokazale, da gre za alogeni sediment, značilen za porečje Cerkniščice (slika 3).

Pobočja jarka brezstrope jame so v južnem in osrednjem delu, kjer je jarek najgloblji, stenasta, pod njimi pa so prekrita z melišči ali večjimi podornimi bloki, ki delno prekrivajo ilovnato zapolnitev v dnu. Severni, plitvejši del odseka brezstrope jame ima blagauravnotežena pobočja, na katerih ni graviklastičnih pobočnih procesov, ampak na njih prevladuje proces korozije.

Podzemni jamski kanali v tem odseku brezstrope jame niso dostopni, saj so popolnoma zapolnjeni z ilovnatim sedimentom, ali pa njihove vhode prekriva pobočni material. Iz morfologije jame ni popolnoma razvidno, ali je bila jama, preden je bil strop denudiran, 
povsem zapolnjena z ilovico, nato pa ilovnat sediment delno spran, ali pa je denudacija stanjšala strop do take mere, da se je porušil strop jamskega rova, ki je bil v dnu zapolnjen z ilovnatim sedimentom. Na severu se odsek brezstrope jame nadaljuje v ilovnati uravnavi Podbojevega laza, na jugu pa pod strmim, $30 \mathrm{~m}$ visokim zatrepom. Nadaljevanje jamskega rova je možno v dveh smereh: ali proti 100 m južneje ležeči udornici Globoščak, ki je razpotegnjena $\mathrm{v}$ isti smeri kot odsek preučevane brezstrope jame, ali proti jugovzhodu, kjer leži okoli 15 m pod površjem Jama pri Malem Globoščaku (kat. št. 3507; Kataster jam JZS 2008).

Slika 3: Teksturni trikotnik z vzorci sedimenta iz brezstrope jame v Podbojevem lazu

Figure 3: Texture triangle with sediment samples from the denuded cave in Podbojev laz

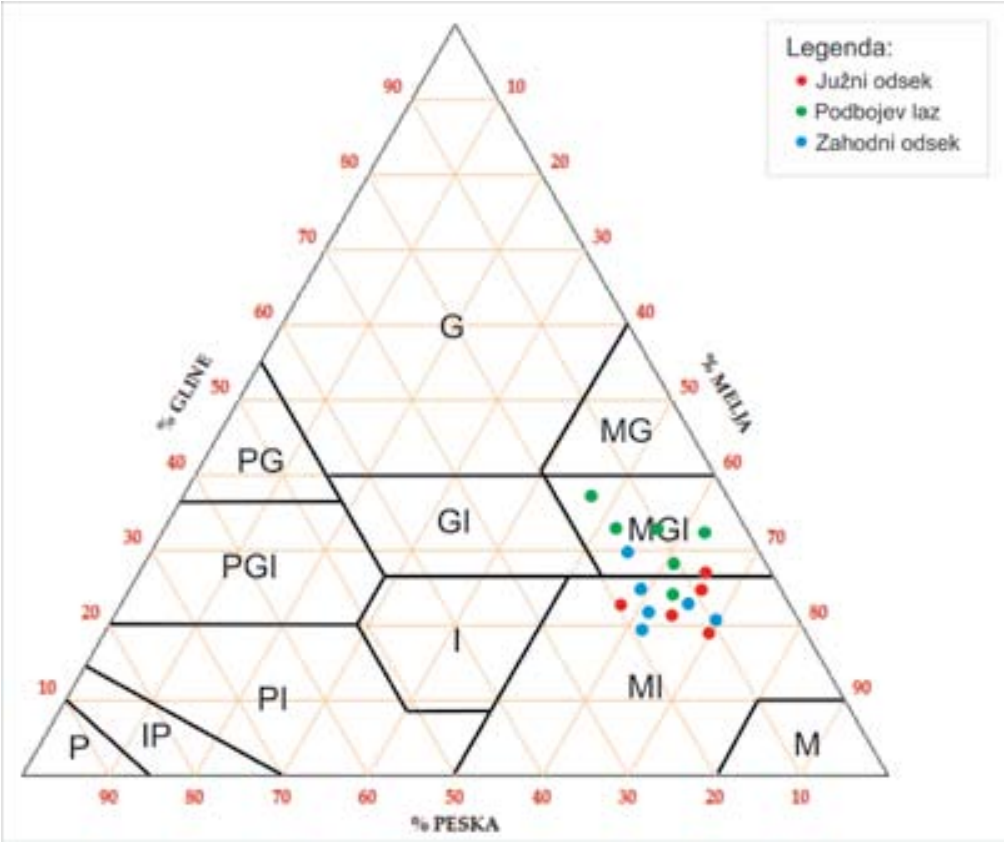

Ker se morfologija dna in pobočij južnega odseka brezstrope jame spreminja na kratke razdalje, je v nadaljevanju opisanih več prečnih profilov preko jarka brezstrope jame, na katerih so podrobno predstavljeni pobočni procesi in zgradba dna (slika 4).

Profil 1: Nahaja se v južnem delu odseka in poteka preko najnižjega dela dna. Jarek brezstrope jame je v tem delu najširši in morfometrično spominja na manjšo udornico. Pod skladnim vzhodnim pobočjem je oblikovano melišče s podornimi bloki različnih velikosti. Nad meliščem je strmo živoskalno pobočje z naklonom $45^{\circ}$. V zgornjem delu vzhodnega, skladnega pobočja je oster prehod v uravnano škrapljasto površje. Na zahodnem neskladnem pobočju so stene z naklonom $70^{\circ}$ visoke $12 \mathrm{~m}$, nad njimi se nadaljuje škrapljasto površje z večjimi, korozijsko zaobljenimi skalnimi bloki. Pod stenami ležijo podorni bloki s premerom 
do enega metra. Dno je konkavno, zapolnjuje ga ilovnat sediment in je široko okoli $20 \mathrm{~m}$. Prekrivajo ga prst in posamezni podorni bloki.

Slika 4: Geomorfološka karta in profili preko južnega odseka brezstrope jame v Podbojevem lazu Figure 4: Geomorphologic map and cross-sections through the southern sector of the denuded cave in Podbojev laz

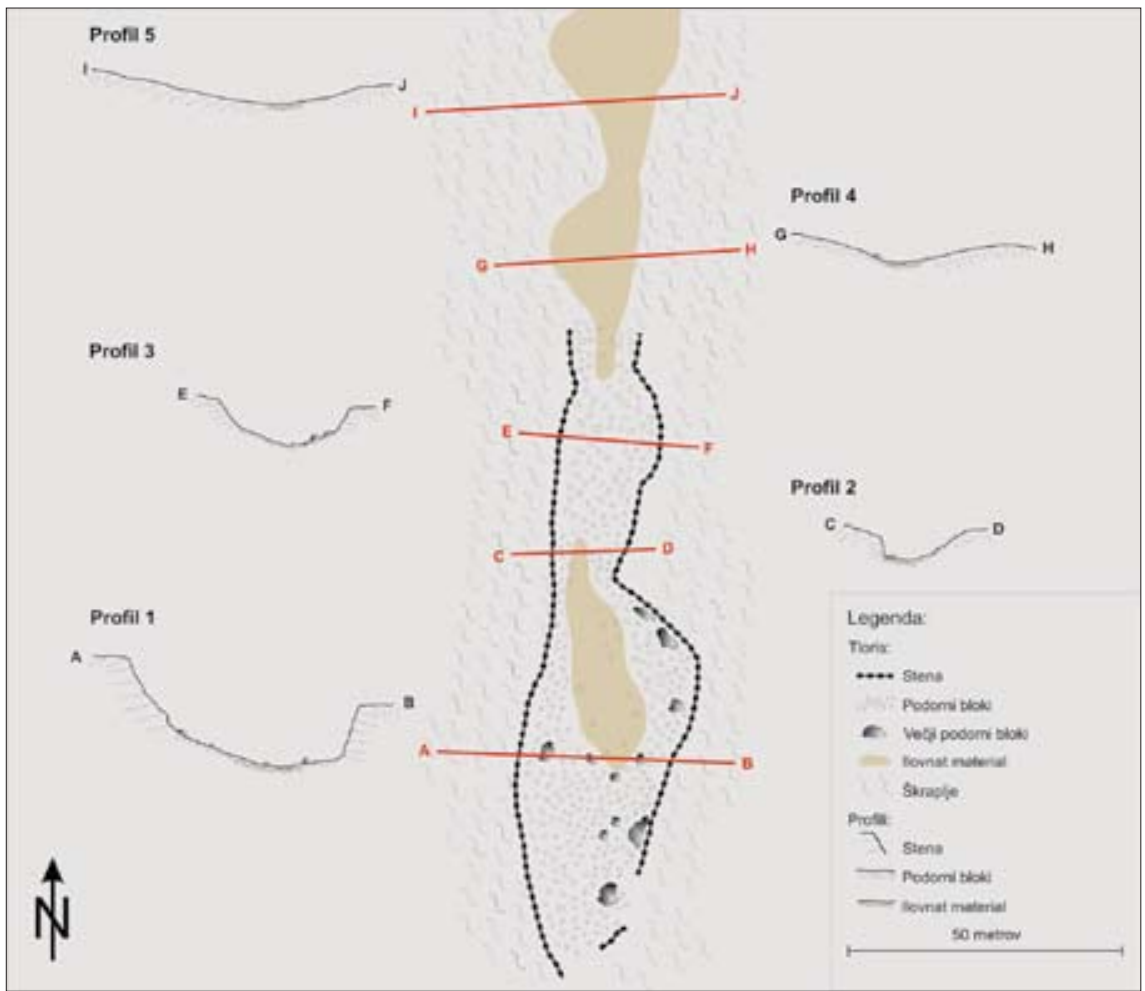

Profil 2: Nahaja se v najožjem delu odseka brezstrope jame in predstavlja prehod med južnim, najglobljim delom jarka, in večjo kotanjo, ki se je oblikovala severneje v jarku. Vzhodno, skladno pobočje prehaja zvezno iz okoliškega škrapljastega površja v živoskalno pobočje $\mathrm{z}$ naklonom $35^{\circ}$ in višino okoli $5 \mathrm{~m}$. Pod njim je akumulacijski del pobočja, prekrit $\mathrm{z}$ manjšimi podornimi bloki. Dno je široko $7 \mathrm{~m}$ in je uravnano $\mathrm{z}$ ilovnatim sedimentom. Zahodno neskladno pobočje je $4 \mathrm{~m}$ visoka vertikalna stena, ki na obodu ostro preide $\mathrm{v}$ uravnano škrapljasto okolico.

Profil 3: Profil poteka preko poglobitve v jarku brezstrope jame. V tem delu je jarek pod stenami zapolnjen s podornim materialom. Ilovnat sediment je bil ali izpran ali pa ga prekriva podorni material. Vzhodno skladno pobočje je $4 \mathrm{~m}$ visoka stena z naklonom $65^{\circ}$. Pod njo so večji podorni bloki s premerom do $2 \mathrm{~m}$ in prekrivajo celotno pobočje. Zahodno pobočje je v spodnjem delu prav tako prekrito $\mathrm{z}$ večjimi podornimi bloki, nad njimi je $6 \mathrm{~m}$ 
visoka stena $\mathrm{z}$ naklonom okoli $60^{\circ}$. Na obeh straneh jarka je oster pregib med pobočjema in okoliškim škrapljastim površjem.

Slika 5: Južni odsek brezstrope jame v bližini profila 1 (pogled proti severu) (foto: B. Burger)

Figure 5: Southern sector of the denuded cave nearby profile 1 (view to the south) (photo: B. Burger)

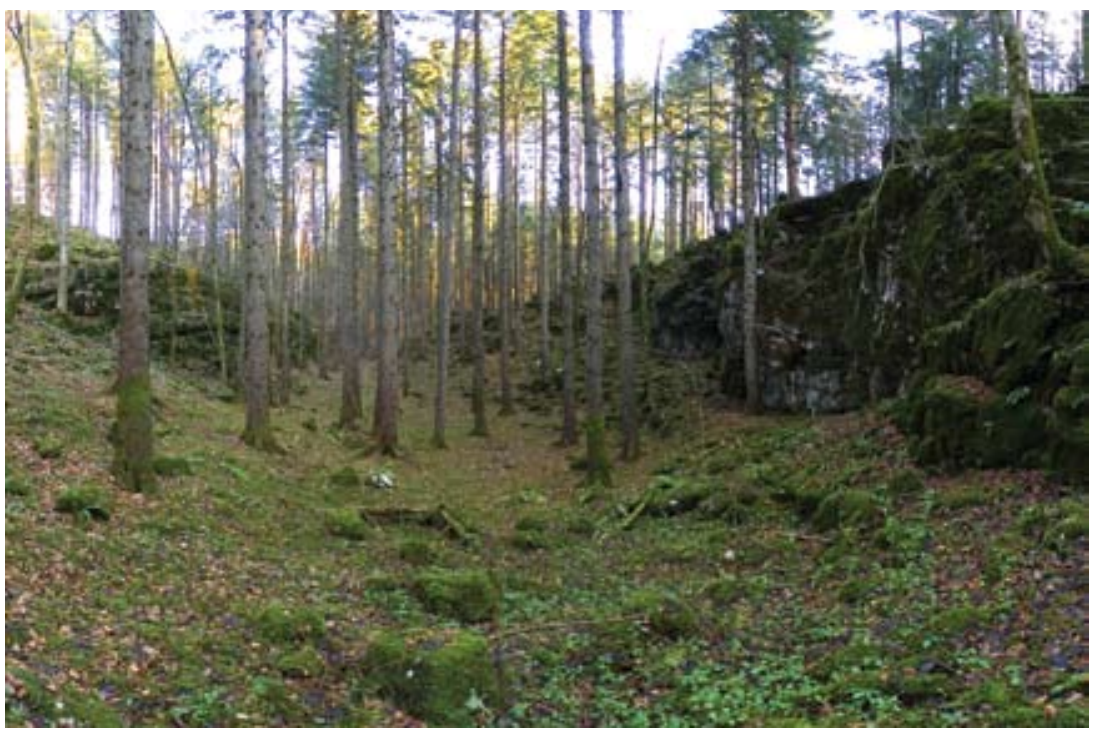

Slika 6: Južni odsek brezstrope jame v bližini profila 3 (pogled proti severu) (foto: B. Burger)

Figure 6: Southern sector of the denuded cave nearby profile 3 (view to the south) (photo: B. Burger)

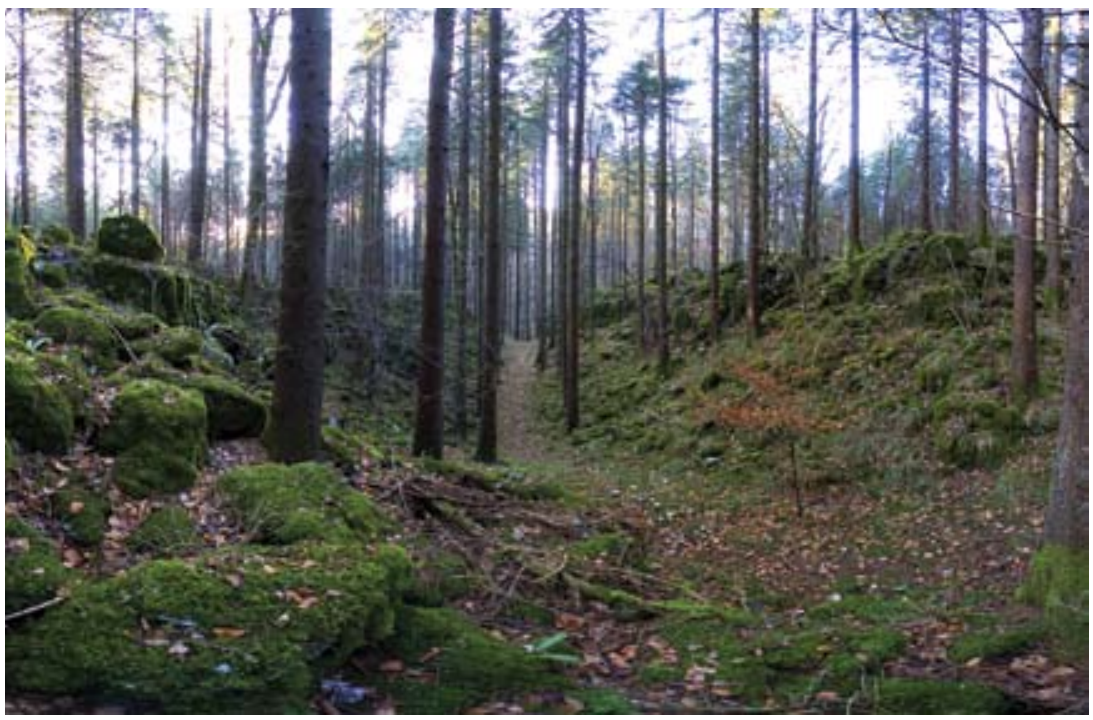


Profil 4: Nahaja se v srednjem delu južnega odseka brezstrope jame, severno od poglobitve. Jarek $\mathrm{v}$ tem delu postane neizrazit $\mathrm{z}$ blagimi pobočji. Vzhodno skladno pobočje blago prehaja v okoliško površje. Naklon pobočja je $14^{\circ}$ in ga prekrivajo zaobljeni, korodirani skalni bloki. Dno je široko okoli $10 \mathrm{~m}$ in je uravnano z ilovnatim sedimentom. Zahodno neskladno pobočje ima $\mathrm{v}$ spodnjem delu en meter visoko živoskalno vertikalno stopnjo, pod katero je na ilovnatem materialu akumuliranih nekaj manjših skalnih blokov. Nad stopnjo je blago škrapljasto površje z naklonom okoli $15^{\circ}$, ki po desetih metrih blago preide $v$ škrapljasto okolico jarka brezstrope jame.

Globina ilovnatega materiala v profilu 4 je bila ugotovljena z meritvami profila električne upornosti tal. Okoli $60 \mathrm{~m}$ dolg profil je bil izdelan pravokotno na smer poteka jarka, v smeri vzhod-zahod. Pod dnom jarka se nahaja vsaj $14 \mathrm{~m}$ globoka in okoli $10 \mathrm{~m}$ široka zapolnitev $\mathrm{z}$ ilovnatim materialom z električno upornostjo do $150 \mathrm{ohm}-\mathrm{m}$. Okolico zapolnitve gradi matična kamnina z električno upornostjo nad 1000 ohm-m (slika 7).

Slika 7: Profil električne upornosti tal v profilu 4

Figure 7: Electrical resistivity profile in the profile 4

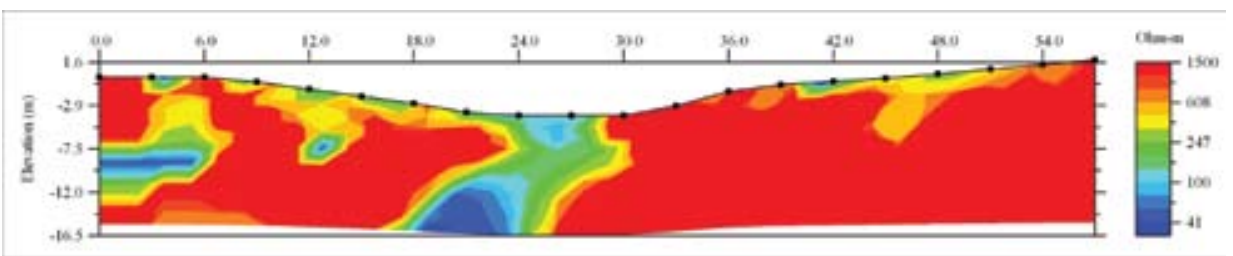

Slika 8: Južni odsek brezstrope jame v bližini profila 5 (pogled proti jugu) (foto: B. Burger)

Figure 8: Southern sector of the denuded cave nearby profile 5 (view to the south) (photo: B. Burger)

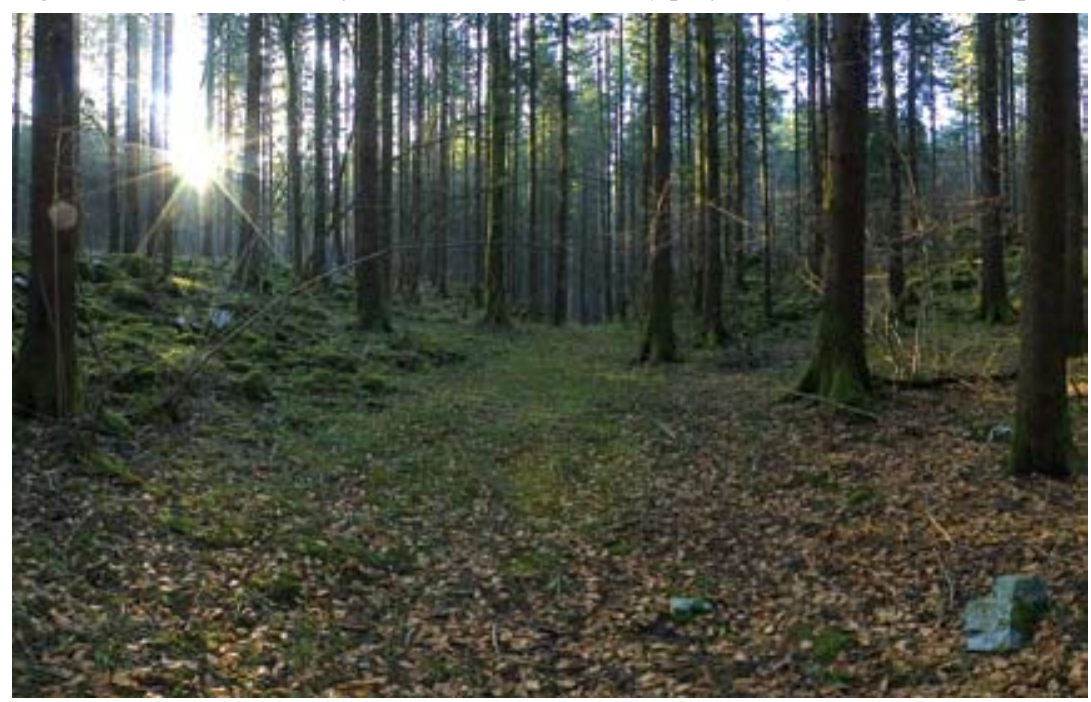


Profil 5: Nahaja se v severnem delu odseka, kjer jarek postopno prehaja v ilovnato uravnavo Podbojevega laza. Vzhodno skladno pobočje blago prehaja v okoliško površje. V zgornjem delu ga prekrivajo korozijsko zaobljeni kosi matične podlage. V spodnjem delu so na pobočju nestabilni bloki kamnine, ki so ob leziki zdrsnili proti dnu. Naklon pobočja je okoli $15^{\circ}$. Dno je široko $8 \mathrm{~m}$, zapolnjeno z ilovnatim sedimentom, ki ga prekriva prst. Zahodno neskladno pobočje je škrapljasto, z naklonom $12^{\circ}$. Po $20 \mathrm{~m}$ zvezno preide v kraško površje.

$\mathrm{V}$ tem delu je bila $\mathrm{z}$ meritvami profila električne upornosti tal ugotovljena podzemna zgradba jarka brezstrope jame. Okoli $60 \mathrm{~m}$ dolg profil je bil izdelan pravokotno na smer poteka jarka, v smeri vzhod-zahod. Pod vzhodnim delom dna jarka se nahaja ilovnata zapolnitev z električno upornostjo do 150 ohm-m, ki je enako kot v profilu 4 globoka vsaj 14 $\mathrm{m}$, široka pa je okoli $6 \mathrm{~m}$ v bližini površja, v globini pa se razširi do $10 \mathrm{~m}$. Okolico zapolnitve gradi matična kamnina $z$ električno upornostjo nad 1000 ohm-m (slika 9).

Slika 9: Profil električne upornosti tal v profilu 5

Figure 9: Electrical resistivity profile in the profile 5

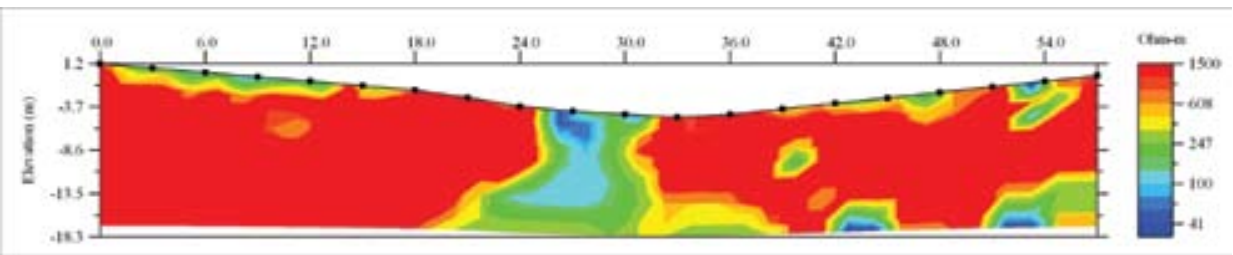

\subsection{Podbojev laz}

Osrednji del brezstrope jame, kamor se stekajo fragmenti rovov brezstrope jame, predstavlja Podbojev laz. To je kotanja v kraškem površju, preko katere poteka cesta iz smeri Postojne in Unca v Rakov Škocjan.

Premer dna kotanje meri okoli $150 \mathrm{~m}$. Zapolnjuje jo ilovnat material, uravnan na nadmorski višini $520 \mathrm{~m}$. Granulometrične analize vzorcev sedimenta so pokazale, da sediment vsebuje 47-63 \% melja, 25-42 \% gline in 5-16 \% peska, kar ga uvršča v teksturni razred meljastoglinaste ilovice. Petrografske analize ilovnatega sedimenta so pokazale, da gre za alogeni sediment, ki nedvomno izvira iz porečja Cerkniščice, saj drobna peščena frakcija sedimenta vsebuje boksite in črne rožence. Prehod med ilovnato uravnavo v dnu in apnenčastimi živoskalnimi pobočji je blag. Na robu dna se nahaja več kotanj v ilovnatem materialu, ki so po vsej verjetnosti nastale zaradi površinskega spiranja ilovice v podzemlje. V osrednjem delu dna se nahajajo tri kotanje z globino $5 \mathrm{~m}$ in premerom do $15 \mathrm{~m}$, ki so najverjetneje sufozijske vrtače. Južni del dna zvezno prehaja v dno južnega odseka brezstrope jame, ki ga prav tako zapolnjuje ilovnat material na nadmorski višini 520-525 m. Prehod v zahodni odsek je manj izrazit in ga predstavlja podolgovata živoskalna kotanja, ki se vleče v smeri proti zahodu. 


\subsection{Zahodni odsek}

Zahodni odsek brezstrope jame se nahaja zahodno od uravnanega dna kotanje Podbojev laz. Sestavlja ga več kratkih jarkov. Od Podbojevega laza vodi jarek brezstrope jame s širino $40 \mathrm{~m}$ in globino okoli $5 \mathrm{~m}$ v smeri zahoda, kjer se po $50 \mathrm{~m}$ izteče v izrazit in globlji jarek brezstrope jame, ki poteka proti jugu. Ta del brezstrope jame poteka $120 \mathrm{~m}$ v smeri severjug, širok je $50 \mathrm{~m}$ in globok do $20 \mathrm{~m}$. Skoraj celotni obod sestavljajo stenasta pobočja, v dnu pa ga uravnava ilovnat sediment. Granulometrične analize vzorcev ilovnatega sedimenta so pokazale, da sediment vsebuje 55-70\% melja, 19-30\% gline in 9-19\% peska, kar ga uvršča $v$ teksturni razred meljaste ilovice. S petrografskimi analizami smo ugotovili, da je tudi $v$ tem delu brezstrope jame ilovnat sediment alogenega izvora, saj je sediment značilen za porečje Cerkniščice. V skrajnem severnem delu se brezstropa jama pod previsno steno nadaljuje v podzemni jamski rov Jame pri Podbojevem lazu (kat. št. 3687; Kataster jam JZS 2008), ki je nedvomno ohranjen del jame, iz katerega se je razvil ta odsek brezstrope jame.

$\mathrm{V}$ severnem delu rova se $\mathrm{v}$ smeri severozahoda odcepi $110 \mathrm{~m}$ dolg razčlenjen jarek, ki ga sestavljata dve vrtači, globoki v povprečju $10 \mathrm{~m}$, med katerima je le $4 \mathrm{~m}$ višji obod. Dno vrtač je uravnano z ilovnatim materialom, pobočja so blaga in prekrita s škrapljami. Jarek se zaključi s strmejšim, delno stenastim zatrepom, nad katerim je škrapljasto površje s skalnimi bloki, velikimi do enega metra. Kakšnih $40 \mathrm{~m}$ severneje od zatrepa se nahaja manjša udornica s premerom $15 \mathrm{~m}$ in globino $10 \mathrm{~m}$. Celoten obod udornice je stenast, dno pa prekrivajo podorni bloki. $\mathrm{V}$ severnem delu dna se odpira $6 \mathrm{~m}$ dolg in $3 \mathrm{~m}$ širok spodmol, ki najverjetneje nakazuje smer podzemnega nadaljevanja tega odseka brezstrope jame.

V nadaljevanju so predstavljeni profili preko jarkov zahodnega odseka brezstrope jame (slika 10).

Profil 7: Nahaja se v južnem delu najglobljega dela jarka brezstrope jame. Vzhodno skladno pobočje gradi $8 \mathrm{~m}$ visoka stena, ki v zgornjem delu prehaja v škrapljasto površje. $\mathrm{V}$ spodnjem delu stene je manjši spodmol, pod steno pa leži več podornih blokov. Dno jarka uravnava ilovnat sediment, ki ga prekriva prst, in je široko $20 \mathrm{~m}$. Zahodno neskladno pobočje prekrivajo v spodnjem delu melišče in večji podorni bloki, nad njimi je oblikovana 9 $\mathrm{m}$ visoka stena $\mathrm{z}$ naklonom $65^{\circ}$. Stena na vrhu ostro preide $\mathrm{v}$ okoliško škrapljasto površje.

Profil 8: Nahaja se v severnem delu jarka okoli $20 \mathrm{~m}$ severneje od profila 7. Uravnana škrapljasta okolica na vzhodni strani sprva neizrazito prehaja v skladno pobočje, ki se nato prevesi v navpično, $8 \mathrm{~m}$ visoko steno, pod katero se nahajajo večji podorni bloki. $15 \mathrm{~m}$ široko dno je uravnano $v$ ilovnatem sedimentu. Zahodno neskladno pobočje ima naklon okoli $30^{\circ}$ in ga v celoti prekrivajo podorni bloki različnih velikosti. Pobočje blago prehaja v škrapljasto okolico brezstrope jame.

Profil 9: Profil poteka pravokotno na razčlenjeni jarek v severozahodnem delu odseka v prehodu med obema vrtačama. Skladno, škrapljasto severovzhodno pobočje je blago, z naklonom okoli $14^{\circ}$. $\mathrm{V}$ spodnjem delu preide $\mathrm{v}$ dno, ki je široko $27 \mathrm{~m}$ in uravnano $\mathrm{z}$ ilovnatim materialom, na njem je nekaj posameznih izdankov korozijsko zaobljene matične kamnine. Jugozahodno neskladno pobočje ima naklon okoli $27^{\circ}$ in je izrazito škrapljasto. Kamninski bloki med škrapljami dosegajo višino $1,5 \mathrm{~m}$. Pobočje zvezno preide v okoliško škrapljasto kraško površje. 
Slika 10: Geomorfološka karta in profili preko zahodnega odseka brezstrope jame v Podbojevem lazu

Figure 10: Geomorphologic map and cross-sections through the western sector of the denuded cave in Podbojev laz

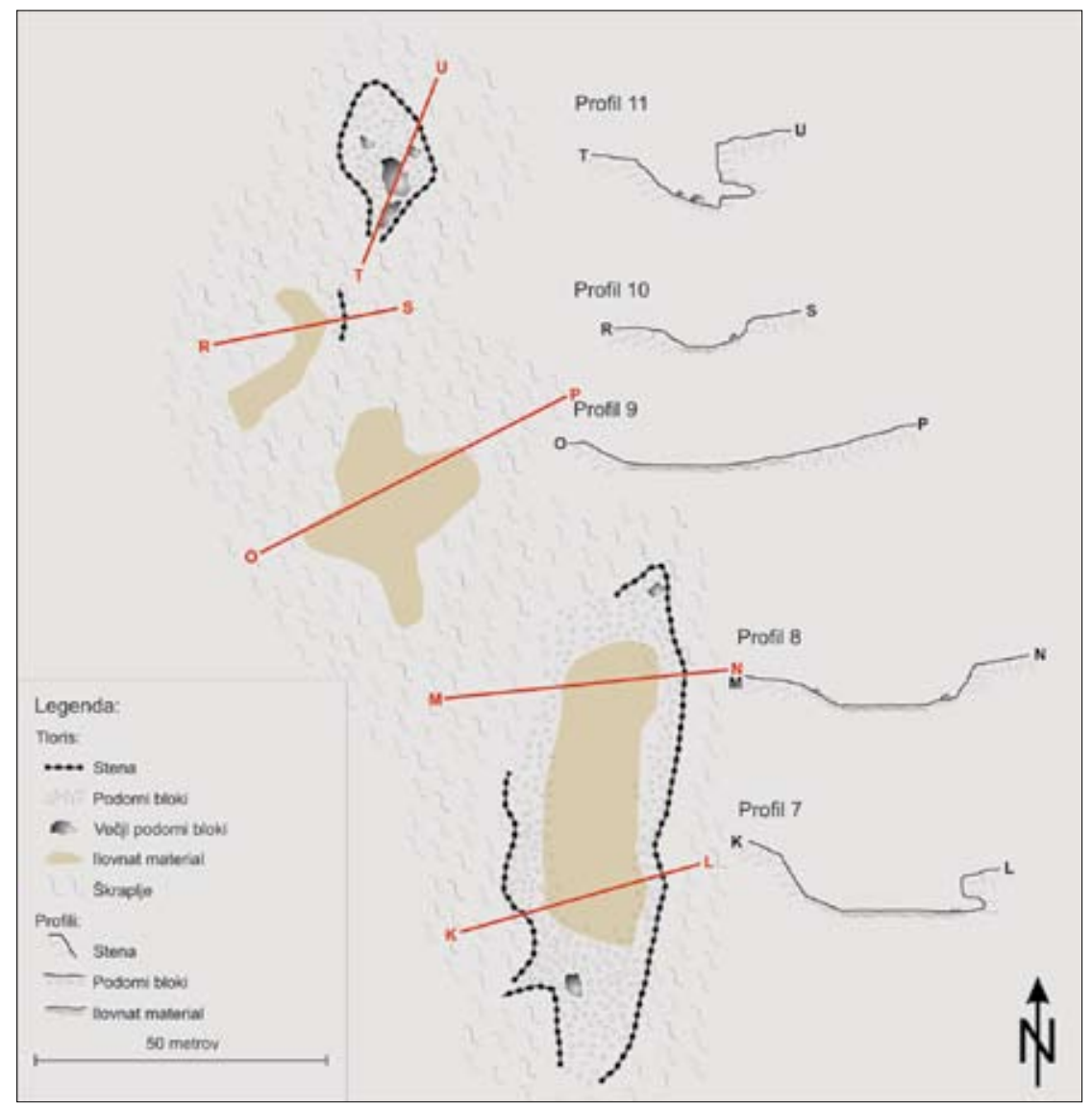

Profil 10: Nahaja se tik pod stenastim zatrepom v skrajnem severozahodnem delu razčlenjenega jarka. Skladna vzhodna stran pobočja prehaja iz uravnanega škrapljastega površja v $4 \mathrm{~m}$ visoko steno, pod katero so nakopičeni podorni bloki različnih velikosti. Tri metre široko dno je uravnano z ilovnatim sedimentom, ki ga prekriva prst. Zahodno neskladno pobočje ima v spodnjem delu nekaj manjših podornih blokov, nato se nadaljuje $\mathrm{v}$ živoskalno pobočje $\mathrm{z}$ naklonom okoli $40^{\circ}$. Prehod med pobočjem in škrapljasto okolico je neizrazit.

Profil 11: Poteka v smeri zahod-vzhod preko udornice, ki je registrirana kot Brezno pri Matildini cesti (kat. št. 3688; Kataster jam JZS 2008), v nadaljevanju odseka brezstrope 
jame. Na vzhodni strani je prehod med okolico in pobočjem oster. Pobočje je $11 \mathrm{~m}$ visoka vertikalna stena. Dno udornice prekrivajo podorni bloki s premerom do $2 \mathrm{~m}$. Dno je široko 8 $\mathrm{m}$. Zahodno neskladno pobočje je $5 \mathrm{~m}$ visoka stena $\mathrm{z}$ naklonom $50^{\circ}$. Zahodno pobočje ostro prehaja $\mathrm{v}$ izrazito razčlenjeno okolico, $\mathrm{s}$ škrapljami globokimi do $1,5 \mathrm{~m}$.

Slika 11: Zahodni odsek brezstrope jame v bližini profila 7 (pogled proti severu) (foto: B. Burger) Figure 11: Southern sector of the denuded cave nearby profile 7 (view to the north) (photo: $B$.

Burger)

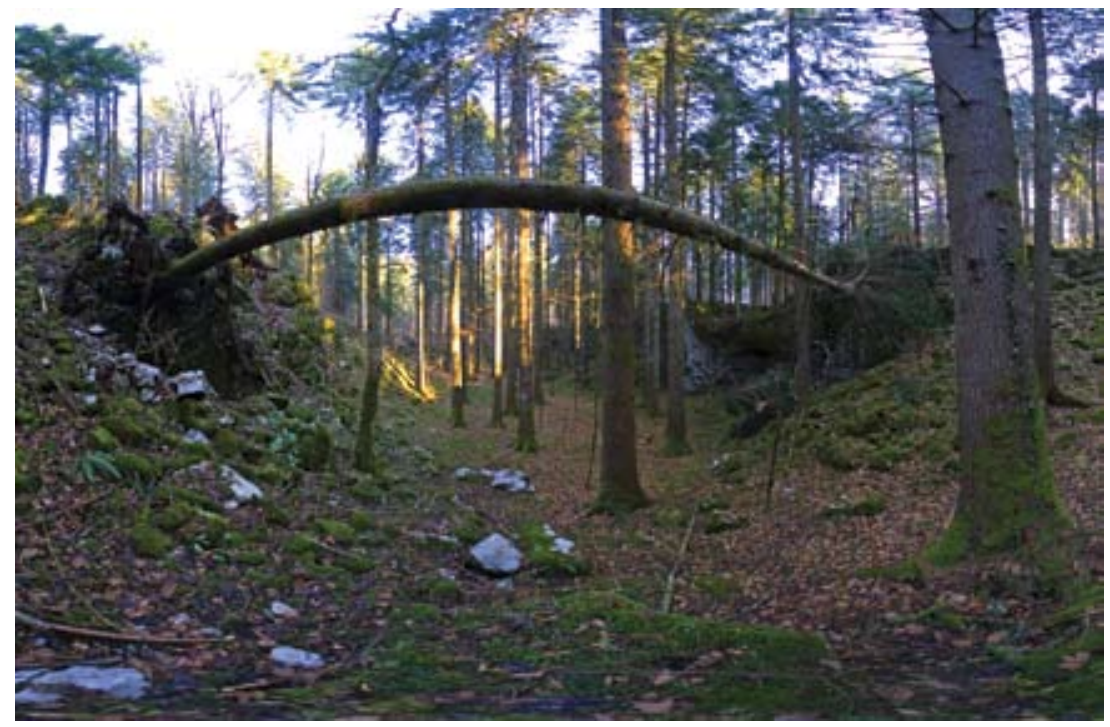

\section{SKLEP}

Rezultati morfogenetske raziskave območja Podbojevega laza so potrdili obstoj daljšega sistema brezstrope jame v njegovi okolici. Podolgovati jarki južnega in zahodnega sektorja, zapolnjeni z alogenim sedimentom, nedvomno potrjujejo, da je oblika vezana na razpad jamskega sistema na površju. Hkrati to potrjujejo tudi udornice južno in jugovzhodno od južnega odseka in v zahodnem odseku. Fragmenti brezstrope jame se večkrat nadaljujejo v spodmole ali v manjše vodoravne jame. Prav tako se v jarkih brezstrope jame nahajajo podorni bloki, ki niso rezultat graviklastičnih procesov na pobočjih; njihov izvor lahko pripišemo razpadu jamskega stropa.

Na podlagi prostorske razdelitve brezstrope jame, zlasti urejenosti na enotnem višinskem nivoju, lahko sklepamo, da so fragmenti brezstrope jame vezani na razpad epifreatičnih jamskih rovov. To hipotezo potrjujejo tudi meritve električne upornosti tal v južnem odseku, ki so pokazale, da se pod jarki brezstropih jam nahajajo globoke, a relativno ozke zapolnitve $\mathrm{z}$ električno manj upornim materialom, najverjetneje alogenim sedimentom, ki se pojavlja 
tudi na površju. Tovrstne zapolnitve in oblikovanost rovov so značilni za preoblikovanje jamskih rovov v epifreatični coni.

Lega fragmentov brezstrope jame v odtočnem delu Rakovega Škocjana, oblikovanost rovov in alogeni sedimenti nakazujejo, da je jama delovala kot odtočni jamski sistem Raka. Raziskave preoblikovanja fragmentov brezstropih jam so odprle številne probleme, katere bo potrebno v prihodnje podrobneje preučiti. Najizrazitejši problem je preoblikovanje pobočij brezstrope jame, oziroma mehanizem in dinamika preoblikovanja pobočij na krasu. Ker območje brezstrope jame ni povsem uravnano, ampak se znižuje proti osrednjemu delu Podbojevega laza, je južni segment brezstrope jame nastajal postopoma. Kjer je bil strop najtanjši, je bila brezstropa jama oblikovana najprej. Severni del južnega odseka ima zato blaga uravnotežena pobočja, prekrita s korozijsko preoblikovanimi skalnimi bloki, medtem ko je južni del globlji, pobočja pa so strma, stenasta z aktivnimi graviklastičnimi procesi. Prav tako lahko v zahodnem sektorju opazujemo različno oblikovanost in procese v pobočjih višje in nižje ležečih segmentov brezstrope jame. Poleg preoblikovanja pobočij prihaja tudi do površinskega in podzemnega spiranja alogenega sedimenta iz dnov jarkov, ki je izrazito predvsem v številnih kotanjah na robovih ilovnatih uravnav in v sufozijskih vrtačah. Dinamika spiranja ilovnatega materiala $\mathrm{v}$ podzemlje prav tako ni bila še nikoli podrobneje preučena.

\section{Zahvala}

Avtorji se zahvaljujemo dr. Andreju Mihevcu in Inštitutu za raziskovanje krasa ZRC SAZU v Postojni za merilec električne upornosti tal Supersting R1/IP. Najlepše se zahvaljujemo tudi recenzentu članka za koristne nasvete in pripombe. Zahvaljujemo se tudi Tjaši Zakšek in Niki Zavašnik, študentkama geografije na Oddelku za geografijo Filozofske fakultete, za pomoč pri geomorfološkem kartiranju in izdelavi podolžnih profilov.

\section{Viri in literatura}

Čar, J., Gospodarič, R. 1983: O geologiji krasa med Postojno, Planino in Cerknico. Acta carsologica 12. Ljubljana.

D’Ambrosi, C. 1966: Considerazioni sull'origine e sul periodo di svolgimento del ciclo carsico in atto nella Venezia Giulia con particolare riguardo all'Istria e al Carso di Trieste. Atti e Memorie della Commissione Grotte »Eugenio Boegan« 5. Trieste.

Dawkins, B. 1876: Die Höhlen und die Ureinwohner Europas. Leipzig.

Gospodarič, R., Kogovšek, J., Luzar, M. 1982: Hidrogeologija in kraški izviri v Rakovem Škocjanu pri Postojni. Acta carsologica 11. Ljubljana.

Habič, P., Gospodarič, R. 1987: The Rakov Škocjan karst valley. V: Man's impact in Dinaric karst. Postojna.

Kataster jam JZS 2008. Jamarska zveza Slovenije. Ljubljana.

Kraus, F. 1894: Höhlenkunde. Wege und Zweck der Erforschung unterirdischer Räume. Wien. Kunaver, P. 1966: Rakov Škocjan. Kulturni in naravni spomeniki Slovenije 6. Ljubljana. 
Mais, K. 1999: Roofless caves, a polygenetic status of a cave development with special references to cave regions in the Eastern Calcareous Alps in Salzburg and Central Alps, Austria. Acta carsologica 28, 2. Ljubljana.

Melik, A. 1955: Kraška polja Slovenije v pleistocenu. Ljubljana.

Mihevc, A. 1996: Brezstropa jama pri Povirju. Naše jame 38. Ljubljana.

Mihevc, A. 2001: Speleogeneza Divaškega krasa. Ljubljana.

Mihevc, A. 2007: Nove interpretacije fluvialnih sedimentov na Krasu. Dela 28. Ljubljana.

Radinja, D. 1967: Vremska dolina in Divaški Kras: problematika kraške morfogeneze. Geografski zbornik 10. Ljubljana.

Radinja, D. 1972: Zakrasevanje v Sloveniji v luči celotnega morfogenetskega razvoja. Geografski zbornik 13. Ljubljana.

Silan, S. 1995: Rakov Škocjan in naravoslovna učna pot. Ljubljana.

Stepišnik, U. 2006: Loamy sediment fills in collapse dolines near the Ljubljanica River springs, Dinaric Karst, Slovenia. Cave and Karst Science 33, 3. Nottingham.

Stepišnik, U., Černuta, L., Ferk, M., Gostinčar, P. 2007: Reliktni vršaji kontaktnega krasa severozahodnega dela Matarskega podolja. Dela 28. Ljubljana.

Stepišnik, U., Mihevc, A. 2008: Investigation of structure of various surface karst formations in limestone and dolomite bedrock with application of the electrical resistivity imaging. Acta carsologica 37, 1. Ljubljana.

Šerko, A. 1949: Kotlina Škocjan pri Rakeku. Geografski vestnik 20-21. Ljubljana.

\section{DENUDED CAVE IN PODBOJEV LAZ, RAKOV ŠKOCJAN}

\section{Summary}

In the string of poljes of the Notranjsko podolje, between Cerknica and Planina poljes, there is a $3.5 \mathrm{~km}$ long and $1.5 \mathrm{~km}$ wide basin of Rakov Škocjan. Its northwestern part is a wide depression called Podbojev laz, about $500 \mathrm{~m}$ long and $250 \mathrm{~m}$ wide. From Podbojev laz, several sections of a denuded cave stretch in southern and western directions, with the total length of $620 \mathrm{~m}$.

The floors of elongated ditches of southern and western sections of the denuded cave are filled with allogenic sediment which is the evidence that this surface feature developed in connection with the disintegration of a cave system on the surface. Evidence of the same process are also numerous collapse dolines to the south and southeast of the southern section and within the western section. Several fragments of the denuded cave continue into smaller caves. Large boulders in the ditches, which do not originate from the slopes, are also clear evidence of the cave roof disintegration.

On the basis of spatial distribution of the denuded cave, particularly arrangement on one distinct elevation level, it can be concluded that the fragments of the denuded cave are associated with the disintegration of an epiphreatic cave system. This hypothesis was also confirmed through electrical resistivity imaging of the profiles in the southern section. The profiles have shown that the ditches of the denuded cave are underlain by deep and narrow infillings of less resistive material, which is presumably fine grained loamy allogenic sediment, 
also found on the floors of depressions. This type of cave infill and passage morphology are typical for transformation of the caves in epiphreatic zone.

The position of the denuded cave in the Rakov Škocjan basin, morphology of the passages and the allogenic sediments show that the cave used to function as an outflow cave system of the river Rak. The study conducted in the denuded cave has revealed numerous issues for further research. Most evident problems are connected with the slopes of denuded caves or the mechanism and dynamics of slope development in karst. Since the surface, in which the denuded cave is exposed, is not flattened but inclined towards the centre of Podbojev laz, the southern section of the cave must have been denuded gradually. The sections with thinner roof were denuded first. Northern part of the southern section has therefore gentle balanced slopes covered with rounded, corroded boulders. Southern part of the section is deeper with steep rock slopes and active graviclastic processes. The same is typical of the western section. Other interesting issues, beside modification of the slopes, are the suffosion and surface and subsurface outwash of the loamy material filling of the denuded cave floors. This process is evident in numerous suffosion dolines and on the edges of loamy infill. The dynamics of the outwash of loamy material has not been studied in detail yet.

(Translated by U. Stepišnik) 